\title{
Optimizing the Growth and Yield of Mungbean (Vigna radiata L.) Cullivars by Altering Sowing Dates
}

\author{
Amjed Ali ${ }^{1}$, Kamran Arooj ${ }^{1}$, Bilal Ahmad Khan ${ }^{1 *}$, Muhammad Ather Nadeem ${ }^{1}$, Muhammad Imran $^{1,2}$, \\ Muhammad Ehsan Safdar ${ }^{1}$, Muhammad Mohsin Amin ${ }^{1}$, Amir Aziz ${ }^{3}$ and Muhammad Fraz Ali ${ }^{4}$
}

${ }^{1}$ Department of Agronomy, College of Agriculture, University of Sargodha, Pakistan; ${ }^{2}$ Institute for Sustainable Food Systems, Department of Agricultural and Biological Engineering; ${ }^{3}$ Department of Soil and Environmental Sciences, College of Agriculture, University of Sargodha, Pakistan; ${ }^{4}$ Department of Agronomy, Faculty of Agriculture, University of Agriculture, Faisalabad, Pakistan.

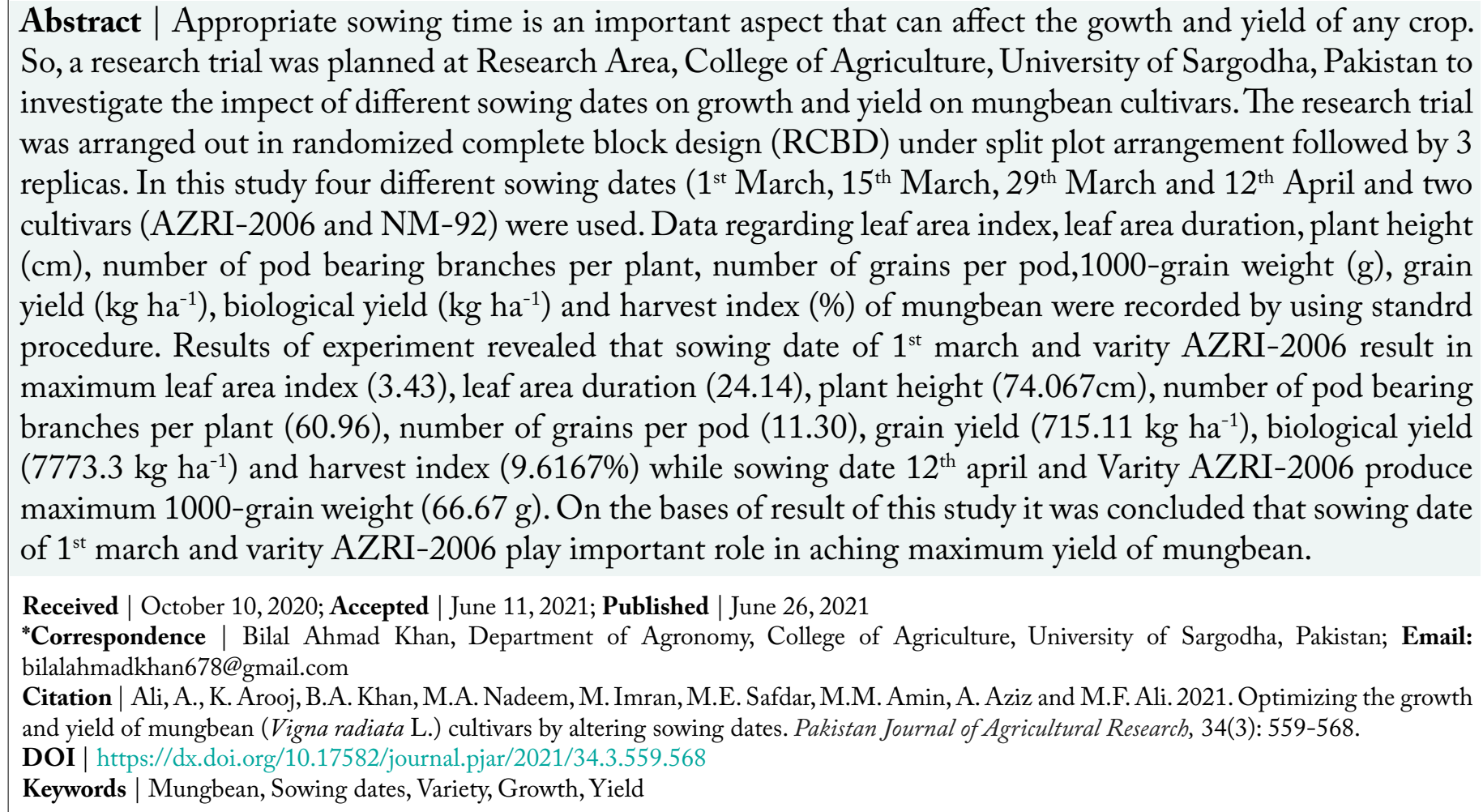

\section{Introduction}

$\mathrm{W}$ orld's population is raising too rapidly and most of world's population is suffering from problem of food scarcity and imbalanced food and nourishment (Garnett, 2013). This is impossible for scientist to feed this rapidly increasing population only through cereal crops. So, grain legumes are playing a vital role in uplifting the quality of diets originated from cereals. Two third of total dietary intake is provided from grain legume together to the developing community of many under developed regions throughout the globe. Agricultural practices and conventional sowing techniques are factors that influence the production of mungbean. Due to the less availability of food resources, the main aim and focus of different research studies to improve soil crop management practices by changing sowing times, production techniques to get higher yield for feeding the rapidly increasing population (Shah and $\mathrm{Wu}, 2019)$. 
Mungbean [Vigna radiata (L.) Wilczek] belongs to Fabaceae family and usually it is known as green gram (Patel et al., 2014). Mungbean is an ancient legume crop that is consumed in traditional Pakistani cuisine as a pulse diet for humans, as hay for nourishment for livestock and also the important source of protein and starch (GOP, 2019). Similar to other pulses produced in Pakistan it holds more protein and less carbohydrates contents, so it is beneficial for the patients which have digestibility and stomach problem (Mondal et al., 2012). Mungbean seed have higher percentage of protein $(28.5 \%)$, fiber $(0.95 \%)$, fats (0.65\%) and ash (3.75\%) (Monem et al., 2012). It is also the source of various vitamins including $A$, $\mathrm{B}_{1}, \mathrm{~B}_{2}, \mathrm{C}$ and niacin. It also contains other mineral nutrients such as $\mathrm{K}, \mathrm{Ca}$ that having important role in human body (Moomow, 1978).

Mungbean is a chief pulse crop of Asia. In Pakistan, it is grown as an important spring and kharif season pulse crop (Amin et al., 2019). In Pakistan it is second largest producing legumes after chickpea (GOP, 2018). It is a short duration crop and got harvest maturitywithin100 days after sowing (Azizur-Rehman et al., 2019). Mungbean has ability to endure water scarcity conditions because of its short life cycle it can be adjusted in cropping systems of spring and summer crops (Raina et al., 2016). The total area under mungbean cultivation during 201819 is 164,000 hectares with a significant production of 118,000 tones and annual production of mungbean is $3.3 \%(\mathrm{GOP}, 2019)$.

Mungbean has ability to fix the nitrogen from atmosphere with the process of symbiosis of microorganisms to maintain the soil fertility. Average rate of atmospheric nitrogen fixed by mungbean is $34 \mathrm{~kg} \mathrm{ha}^{-1}$ annually (Torabian et al., 2019; Khan et al., 2020). Mungbean seed yield decreases when it is intercropped with sugarcane, sunflower and cereals but it increases the productivity of land (Awaad and El-Naggar, 2018). Beside agronomic practices there are two main important factors i.e. sowing date and varietal potential are responsible for increasing mungbean growth and seed yield (U1lah et al., 2010). By considering mungbean growth, development and yield, optimum sowing time is the utmost important element for increasing crop yield (Soomro and Khan, 2003). There is variability in the optimum sowing time for each variety according to its agro-ecological zone requirements (Chahuan and Rachaputi, 2014).
Mungbean growth and yield is not optimal in our country due to various agronomic and environmental factors affecting its production. As we compared with other legume crops, per hectare seed yield of mungbean crop is very low due to lack of well systemized production technology and no new introduction of mungbean variety in past years. Other factors for its yield reduction include improper sowing time, less seed rate, low potential cultivars and poor agronomic practices (Singh et al., 2015). Mungbean is low in sulfur-containing amino acid with even low methionine than lysine which makes its protein effectively digestible than other vegetables. Therefore, the mungbean is more nutritious when mixed with cereals (Sharma et al., 2011). Because of its dietary advantages and nitrogen-fixing ability mungbean is the best choice to fulfill dietary requirements and it is becoming a very important crop within the developing countries (Raza et al., 2012)

There are many cultivars of mungbean in Pakistan which have different yield potential according to its agro-ecological zone. By planting high yielding mungbean cultivars, we can boost its yield potential in Pakistan (Abbas et al., 2018). By adopting recommended agronomic practices and following the optimum nutrition and irrigation plan mungbean potential yield can be achieved. Most essential aspects that can alter the productivity of mungbean which includes high potential yield cultivars and optimum sowing time. Optimum germination can't be achieved in too early sowing of mungbean while late sowing of mungbean have reduced grain yield because of punitive environmental conditions for optimum growth and development phases of mungbean crop (Hussain and Khalil, 2004). So, potential yielding cultivars of mungbean and their sowing at the appropriate time can boost its yield.

Rehman et al. (2009) reported that by adopting optimum sowing time significantly increase the growth and yield parameters in mungbean crop. According to meteorological data, early sown mungbean cultivars obtain more monsoon rain then late sown cultivar. Early sown crop achieves its extreme vegetative growth before flowering stage which results in higher number of pods and grain filling due to optimum time of pollination while late sown crop passes from the harsh climatic condition which was resulted in lower grain yield (Singh and Singh, 2011). In view of overall discussion, it is clear 
that yield is increased by sowing crop at proper time and using the high yielding cultivars (Ali and Gupta, 2012). Keeping in mind the significance of sowing dates and importance of yield potential of mungbean cultivars a research study was completed to estimate the effect of different planting dates on growth and yield of mungbean cultivars.

\section{Materials and Methods}

\section{Experimental location and soil profile}

The current research trial was performed at College of Agriculture, Sargodha, Pakistan during spring season 2018 to explore the influence of sowing dates on two mungbean cultivars. Soil was analyzed before sowing of crop. The physiochemical characteristics of experiment soil are given in Table 1.

Table 1: Physiochemical soil analysis of experimental soil.

\begin{tabular}{lllll} 
Characteristics & \multicolumn{4}{l}{ Soil depth (cm) } \\
& $\mathbf{1 0}$ & $\mathbf{1 5}$ & $\mathbf{2 0}$ & Mean \\
pH of soil & 8.6 & 8.4 & 8.3 & 8.43 \\
OM (\%) & 1.25 & 1.04 & 1.11 & 1.13 \\
Phosphorus $\left(\mathrm{mg} \mathrm{kg}^{-1}\right)$ & 7.1 & 8.8 & 6.6 & 7.5 \\
Potassium $\left(\mathrm{mg} \mathrm{kg}^{-1}\right)$ & 164 & 172 & 150 & 162 \\
Saturation $(\%)$ & 40 & 40 & 40 & 40 \\
Texture & Loam & Loam & Loam &
\end{tabular}

\section{Experimental design and treatment}

The research trial was arranged out in randomized complete block design (RCBD) under split plot arrangement followed by 3 replicas.4sowing dates $\left(1^{\text {st }}\right.$ March, 15 ${ }^{\text {th }}$ March, 29 ${ }^{\text {th }}$ March and 12 ${ }^{\text {th }}$ April) were placed in main plots and two cultivars (AZRI-2006 and NM-92) in subplots.

\section{Land preparation}

Soil was prepared by two cultivation before rauni irrigation to saturate the soil particles in order to get suitable moisture. When the rauni irrgation was applied then field was left for its setting to watter conditons. When the field comes in watter conditons, then three cultivations followed by planking was applied in order to save the soil moisture by breaking soil capillaries to reduce evaporation chances.

\section{Sowing method and cultural practices}

When the field was in proper watter conditions then sowing of mungbean was done with the assistance of hand drill by keeping R X Rspace of $30 \mathrm{~cm}$ and P X Pspace of $10 \mathrm{~cm}$. For optimum plant population seed @ 24 killo gram per hectare was used. Application of fertilzier at sowing timeas Urea and DAP with the recommended doses of nitrogen, phosphorus and potassium. In order to fulfill mungbean water requirement during crop growing season, 3 irrigations were pragmaticat following growth stages i.e $1^{\text {st }}$ at branching, $2^{\text {nd }}$ at flowering and $3^{\text {rd }}$ at grain filling stage.

\section{Crop protection measures}

Weeds control: Weeds were controlled manually and chemically during its growing cycle. Pre and post emergence herbicde pendimethalin $30 \mathrm{EC}$ and quizalofop-ethyl $10 \mathrm{EC}$ was used respectively. Manual control includes hand weeding and hoeing, when the field comes in watter conditons after $1^{\text {st }}$ and $2^{\text {nd }}$ irrigation weeds were controlled by hoeing and after $3^{\text {rd }}$ irrigation weeds was controlled by hand weeding in order to obtain better crop stand.

Pest control: Insects including whitefly, thrips, jassids, aphids, milleybugs, army worm and borrers have a severe attack on mungbean crop which influence its yield potential. For control of these insect pests bifenthrin, emamectin, segapest cleare were applied with the help of motarized knpasack sprayer.

Disease control: Mungbean yellow mosaic virus (MYMV) and anthracnose was diseases which was observed during research trial and controlled by using imidacloprid for control of whitefly population in MYMV while later was control with application of fungicide metalaxyl+mancozeb.

Data recroding: The data of the current research experimentwas recorded by following stardard agronomic procedures.

\section{Leaf area index (LAI)}

LAI was a unit less plant parameter that indicateplant occupied canopy. It is obtained by dividing of plant leaf area overplant land area (Watson, 1947). Leaf sample of $5 \mathrm{~g}$ green leaf lamina was taken from each plot for the calculation of leaf area by using leaf area meter (JVC Model TK-S310EG).

$$
\text { LAI }=\frac{\text { Total leaf area }}{\text { Total land area }}
$$


Leaf area duration (LAD)

LAD is the relationship between leaf area index which is dignified against time.It was caluculated with the help of follwing formulaanticipated by Hunt (1978).

$$
\mathrm{LAD}=\frac{\mathrm{LAI} 1+\mathrm{LAI} 2}{2} \times \mathrm{T} 2-\mathrm{T} 1
$$

Where;

LAI1 is leaf area index at time interval T1; and LAI2 is leaf area index at timer interval T2; T1 and T2 are time intervals; Final LAD was determined at absolute harvest by additionwhole LADs values.

\section{Plant height $(\mathrm{cm})$}

Plant height can be given as the distance measured from uper edge of leaf to lower gorund boundary at adjoining point of root-shoot. In this 10 plants were takencasually from every treatament plot and their plant height was recorded with the help of measuring tape from base of plant to tip of the plant at its physiological maturity stage and then average was computed.

\section{Number of pod bearing branches per plant}

Branches which have pods on them are called pods bearing branches. 10 plants from eachtreatment plotwas selected randomly forcounting the number of pod bearing branches per plant and then average was computed.

\section{Number of grains per pod}

Grains which are present in a single pod is called number of grains per pod. 10 pods were casually selected from bulk of pods removed from ten plants in each treatment plot to count pods numberfor every plant. Average grains per pod was computed to better understand overall grains per pod.

\section{0-grain weight $(g)$}

Weight of 1000-grains is calculated with the help of electric balance. For this random sample of 1000 grains were taken from every treatment plot and their weight was recorded.

\section{Grain yield ( $\left.\mathrm{kg} \mathrm{ha}^{-1}\right)$}

Grain yield was calculated from manual threshing of half plot area of each experimental unit and is recorded into kilo grams. And then it is converted into $\mathrm{kg} \mathrm{ha}^{-1}$.

\section{Biological yield $\left(\mathrm{kg} \mathrm{ha}^{-1}\right)$}

Biological yield was estimated from each experimental unit by converting the biological yield of three plants into $\mathrm{kg} \mathrm{ha}{ }^{-1}$.

\section{Harvest index (\%)}

Harvest index is the defined as of grain yield over biological yield. It was computed by using following formula.

$$
\text { Harvest index }=\frac{\text { Grain yield }}{\text { Biological yield }} \times 100
$$

\section{Statistical analysis}

Recorded data ofall growth, yield and physiological parameters were tabulated and analyzed using statistical software Statisitics 8.1and employing using Fisher's ANOVA technique and their means was comparred by using least significance difference (LSD) at level of 5\% probability (Steel et al., 1997).

\section{Results and Discussion}

\section{Leaf area index (LAI)}

Leaf area index (LAI) is an imperative parameter of crop growth because it has an important role to capture the PAR. If there will be the higher leaf area index more will be the chances of solar radiations to strike on leaves rather than striking on land. These striked solar radiation will be converted into carbohydrates by the process of photosynthesis which will utimately effect crop biomass. Highly significantly result of diversesowing dates and mungbean cultivars on LAI was observed in Table 1 . For sowing dates maximum LAI (3.92) was observed by $1^{\text {st }}$ March sowing followed by $15^{\text {th }}$ March (3.41), 29 ${ }^{\text {th }}$ March (3.06) and $12^{\text {th }}$ April (2.83) respectively.In case of cultivars both are statistically different from each other, maximum LAI (3.43) was obtained from AZRI-2006 and minimum (3.17) was recorded by NM-92. Statistically nonsignificant results were obtained during interaction between sowing dates and cultivars. The gradual changes in LAIwith time is also indicated in Figures 1 and 2. The possible reason for significant difference of LAI in case of sowing dates manipulation may be due to favourable growth conditions in case of early planted crop. The significant difference in case of varieties may be to genetic difference of each variety.

\section{Leaf area duration (LAD) (days)}

It is a growth parameter but its main role is for crop biomass. Higher the leaf area duration higher will be the crop biomass. Data reported in Table 1 
demonstrated that leaf area duration was significantly affected due to sowing dates. The maximum leaf area duration (23.00) was achieved by $1^{\text {st }}$ March sowing and minimum leaf area duration(16.35)was observed in $12^{\text {th }}$ April.Among cultivars maximum leaf area duration was recorded by AZRI-2006 (20.05) and minimum by NM-92 (18.46). However, in case of interaction between sowing dates and mungbean cultivars upsetting the LAD was non-significant as given and presented in Table 1 .

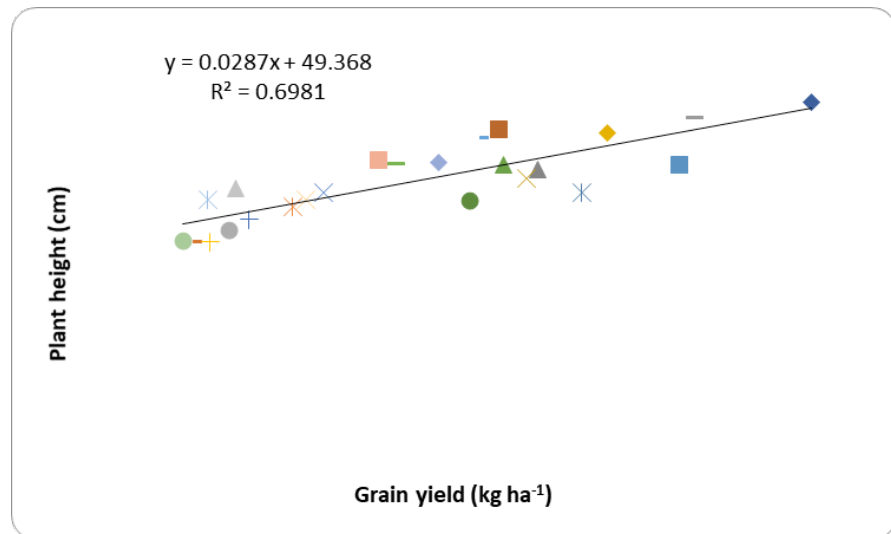

Figure 1: Relationship between plant height and grian yield $(\mathrm{kg}$ $\left.h a^{-1}\right)$.

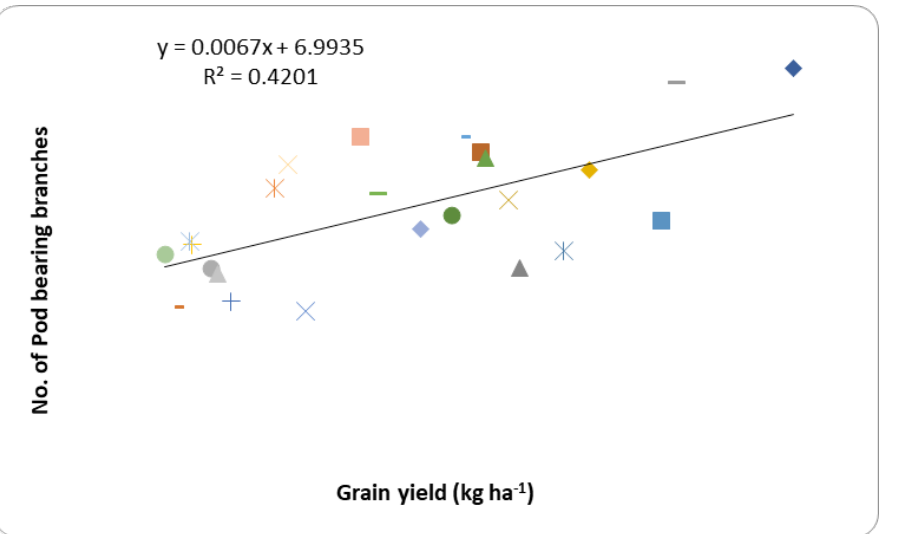

Figure 2: Relationship between number of pod bearing branches and grian yield $\left(\mathrm{kg} \mathrm{ha}^{-1}\right)$.

\section{Plant height at maturity $(\mathrm{cm})$}

Plant height is an imperative feature of crop growth in every crop as it performs a vital part in genetic composition to which plant is imperiled during its growth cycle. From results it was concluded that influence of sowing times and cultivars had highly significant effect on plant height (Table 1 ). Maximum plant height $(71.88 \mathrm{~cm})$ was attained in $1^{\text {st }}$ March sowing date and lowest plant height (53.41) was observed in $12^{\text {th }}$ April sowing. It was observed that plant height was reduced due to delay in sowing dates. In case of variety maximum plant height (63.90) was attained by AZRI-2006. In case of interaction maximum plant height (74.06) was observed in AZRI-2006 when sown at $1^{\text {st }}$ March.

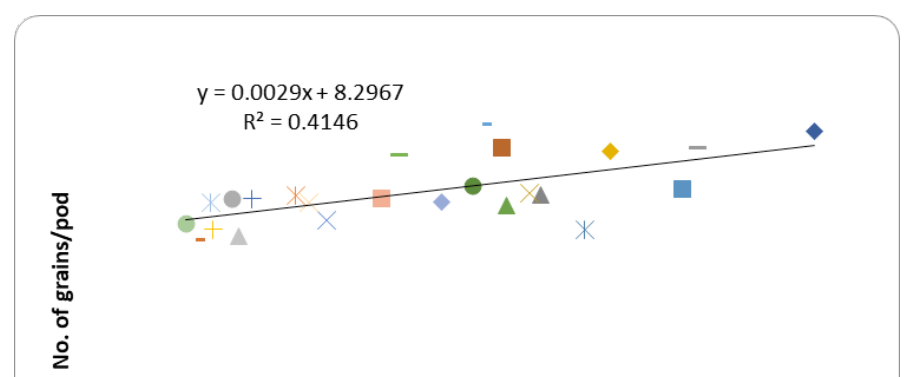

Grain yield (kg ha-1)

Figure 3: Relationship between number of grains per pod and grian yield $\left(\mathrm{kg} \mathrm{ha}^{-1}\right)$.

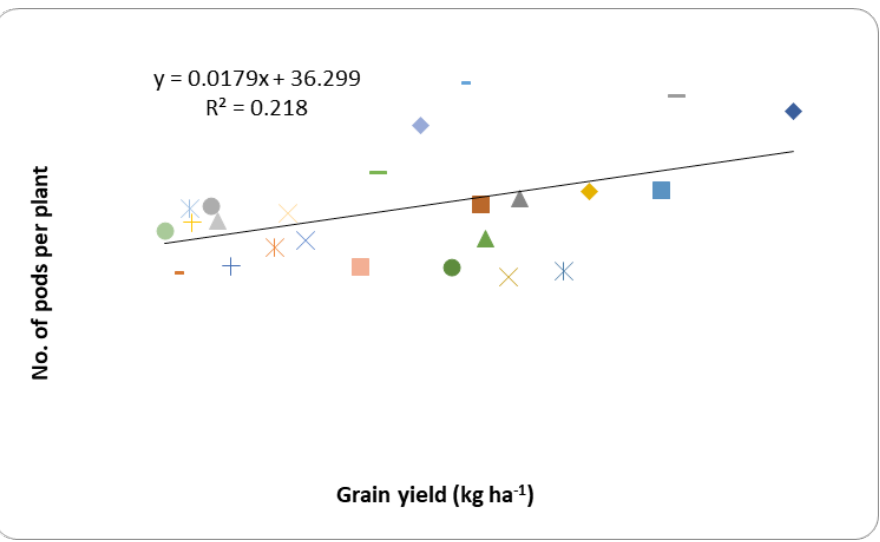

Figure 4: Relationship between number of pods per plant and grian yield $\left(\mathrm{kg} \mathrm{ha}^{-1}\right)$.

Number of pods bearing branches per plant

Yield of mung bean is fully dependent on its pods bearing branches. Higher yield of mungbean crop is solely depends on the highest number of pods bearing branches (Figure 2). For the current research experiment data related to number of pods bearing branches per plant in Table 1. Data indicated that treatments differs significantly. Highest pods bearing branches (13.86) were formed by cultivar AZRI-2006 when sown on $1^{\text {st }}$ March and minimum number of pods bearing branches (7.76) was attained by NM-92 when sown on $12^{\text {th }}$ April.

\section{Number of grains per pod (NGPP)}

Number of grains per pod (NGPP) is an important feature that unswervingly linked to the possible highest yield of legume crops. It is the final product at harvest and important source of human food. Data concerning to NGPP is presented in Table 2. A significant difference was found in all sowing dates due to difference in growth conditions of the crop. 
It was observed that earlier sown cultivar produced a greater number of grains per pod (11.30) than late planted cultivars (8.46). This may be due to more time span enjoyed by earlier planted cultivars to complete their vegetative and reproductive growth. On the other hand, cultivars showed non-significant effect with respect to number of grains per pod (Figure 3).

Table 2: Effect of different sowing dates on the growth of mungbean.

$\begin{array}{lllll}\text { Treatments } & \begin{array}{l}\text { Leaf } \\ \text { area } \\ \text { index }\end{array} & \begin{array}{l}\text { Leaf area } \\ \text { duration }\end{array} & \begin{array}{l}\text { Plant } \\ \text { height } \\ \text { (cm) }\end{array} & \begin{array}{l}\text { Number o } \\ \text { pod bearin } \\ \text { branches }\end{array} \\ \text { Sowing dates } & & & & \\ \mathrm{D}_{1}=1^{\text {st }} \text { March } & 3.92 \mathrm{a} & 23.00 \mathrm{a} & 71.883 \mathrm{a} & 54.16 \mathrm{a} \\ \mathrm{D}_{2}=15^{\text {th }} \text { March } & 3.41 \mathrm{~b} & 19.90 \mathrm{~b} & 65.083 \mathrm{~b} & 43.48 \mathrm{~b} \\ \mathrm{D}_{3}=29^{\text {th }} \text { March } & 3.06 \mathrm{c} & 17.76 \mathrm{c} & 59.483 \mathrm{c} & 40.81 \mathrm{c} \\ \mathrm{D}_{4}=12^{\text {th }} \text { April } & 2.83 \mathrm{~d} & 16.35 \mathrm{~d} & 53.417 \mathrm{~d} & 39.55 \mathrm{~d} \\ \mathrm{LSD} & 0.18 & 0.94 & 4.51 & 2.93 \\ \text { Cultivars } & & & & \\ \mathrm{V}_{1}=\mathrm{AZRI}-2006 & 3.43 \mathrm{a} & 20.05 \mathrm{a} & 63.90 \mathrm{a} & 48.09 \mathrm{a} \\ \mathrm{V}_{2}=\mathrm{NM}-92 & 3.17 \mathrm{~b} & 18.46 \mathrm{~b} & 61.03 \mathrm{~b} & 40.91 \mathrm{~b} \\ \mathrm{LSD} & 0.06 & 0.30 & 1.14 & 2.39 \\ \text { Interaction } & & & & \\ \mathrm{D}_{1} \times \mathrm{V}_{1} & 4.08 & 24.14 & 74.067 & 60.96 \mathrm{a} \\ \mathrm{D}_{1} \times \mathrm{V}_{2} & 3.76 & 21.87 & 69.700 & 47.36 \mathrm{~b} \\ \mathrm{D}_{2} \times \mathrm{V}_{1} & 3.55 & 20.71 & 65.267 & 50.03 \mathrm{~b} \\ \mathrm{D}_{2} \times \mathrm{V}_{2} & 3.26 & 19.09 & 64.900 & 36.93 \mathrm{~d} \\ \mathrm{D}_{3} \times \mathrm{V}_{1} & 3.14 & 18.32 & 60.500 & 39.43 \mathrm{~cd} \\ \mathrm{D}_{3} \times \mathrm{V}_{2} & 2.97 & 17.21 & 58.467 & 39.66 \mathrm{~cd} \\ \mathrm{D}_{4} \times \mathrm{V}_{1} & 2.96 & 17.04 & 55.767 & 41.93 \mathrm{c} \\ \mathrm{D}_{4} \times \mathrm{V}_{2} & 2.71 & 15.67 & 51.067 & 39.70 \mathrm{~cd} \\ \mathrm{LSD} & \mathrm{NS} & \mathrm{NS} & \mathrm{NS} & 2.40 \\ & & & & \end{array}$

1000-grain weight (g)

Among various growth and yield parameters, the most important and promising factor that contributes toward yield is 1000 -grain weight of mungbean. Data regarding 1000-grain weight is given in Table 2 . Results directed that sowing dates and cultivars had positive effect on 1000-grain weight but interaction effect of sowing dates and cultivars had negative effect on 1000-grains of mungbean. Maximum 1000-grain weight $(66.67 \mathrm{~g})$ was obtained from treatment $\mathrm{D}_{4}$ (12 ${ }^{\text {th }}$ April) sowing with $\mathrm{V}_{1}$ cultivar (AZRI-2006) and minimum 1000-grain weight $(40.0 \mathrm{~g})$ was obtained from $\mathrm{D}_{3}\left(29^{\text {th }}\right.$ March) with NM-92 (Figure 5).

\section{Grain yield $\left(\mathrm{kg} \mathrm{ha}^{-1}\right)$}

Grain yield is the final product and vital goal of farmer.
Grain yield can be acquired from the contribution of various yield factors which includes height of plant, (pod bearing branches, number of pods, grains, 1000-grain) per plant, and harvest index of the crop. The consequence of sowing dates and cultivars on the grain yield of mungbean is shown in Table 2. Results from current research study reveals that both sowing dates and cultivars had a positive result on grain yield of mungbean. Uppermost grain yield was observed in $\mathrm{D}_{1}\left(1^{\text {st }}\right.$ March) sowing and minimum grain yield was obtained from $\mathrm{D}_{4}\left(12^{\text {th }}\right.$ April) sowing. Highest grain yield was recorded in early plantation because they have highest number of pods per plant, grains per pod and grain yield for mungbean. AZRI-2006 has the highest grain yield followed by NM-92.

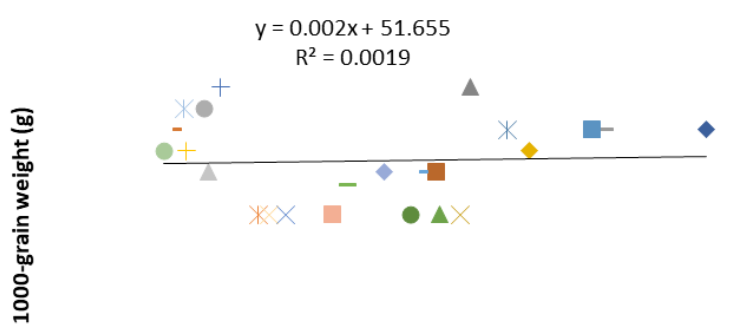

Grain yield $\left(\mathrm{kg} \mathrm{ha}^{-1}\right)$

Figure 5: Relationship between 1000-grain weight $(g)$ and grian yield $\left(\mathrm{kg} \mathrm{ha} \mathrm{a}^{-1}\right)$.

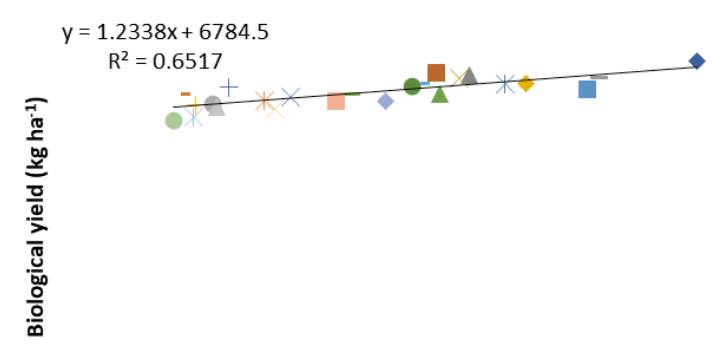

Grain yield (kg ha-1)

Figure 6: Relationship biological yield $\left(\mathrm{kg} \mathrm{ha}^{-1}\right)$ and grian yield ( $\mathrm{kg}$ $\left.b a^{-1}\right)$.

\section{Biological yield $\left(\mathrm{kg} \mathrm{ha}^{-1}\right)$}

Biological yield can be given as "the total biomass produced by the crop throughout the growing season". It has an important function in both genetic makeup of crop and experimental conditions to which crop is exposed during its whole developmental period. The results from observation showed highly significant upshot of sowing dates and cultivars on biological 
yield of mungbean (Table 2). The maximum biological yield was obtained from $\mathrm{D}_{1}\left(1^{\text {st }}\right.$ March) sowing and minimum was obtained from $\mathrm{D}_{4}\left(12^{\text {th }}\right.$ April $)$ sowing. It is evaluated that biological yield of mungbean decreased with delay in sowing date because more time was available for early planted crop to complete its vegetative growth in comparison with late planted crop. Early planted crop enjoyed more sunlight which in results with luxurious growth of plant. In case of cultivars AZRI-2006 produced maximum biological yield than NM-92 (Figure 6).

\section{Harvest index (\%)}

Harvest index can be defined as the portion of total dry matter production that is converted into economically harvestable product. It also decides the ability of plant to translocate the photosynthetic material to the economical part of the plant. Harvest index gives the physiological efficiency of crop that is significant parameter for altering the TDM of crop into yield of grains. Data concerning HI for current research experiment are given in Table 2. Current reveals that both sowing dates and cultivars had substantial effect on harvest index. Among cultivars AZRI-2006 was at top in terms of harvest index than NM-92. In case of sowing dates $\mathrm{D}_{1}\left(1^{\text {st }}\right.$ March) sowing produced highest harvest index $(8.4867 \%)$ and $\mathrm{D}_{4}$ produced lowest harvest index $(2.9517 \%)$. However, sowing dates and mungbean cultivars have non-significant interaction.

Our results are in line to the findings of Islam et al. (2011) in their results maximum leaf area index was obtained by variety MBM-18 and minimum by $\mathrm{N}_{2} \mathrm{M}-402$. These results were supported with the results of Hozayn et al. (2007) who reported that cultivars showed significant difference for leaf area duration. The possible reason for decreasing trend of leaf area duration may be due the changes in the environmental conditions.

Singh et al. (2010) studies also reported significant effect of sowing dates and on plant height. These results were supported by Kumar and Kumawat (2014) who reported significant interaction of mung bean in the case of plant height. The significant effect of sowing date and variety on plant height may be due to differences in the growth periods. As early sown variety enjoyed more time to complete their life cycle from germination to maturity which ultimately causemore plant height than crop which was late planted.

Table 3: Effect of different sowing dates on the yield of mungbean.

\section{Treatments}

\section{Sowing dates}

$\mathrm{D}_{1}=1^{\text {st }}$ March

$\mathrm{D}_{2}=15^{\text {th }}$ March

$\mathrm{D}_{3}=29^{\text {th }}$ March

$\mathrm{D}_{4}=12^{\text {th }}$ April

LSD

Cultivars

$\mathrm{V}_{1}=\mathrm{AZRI}-2006$

$\mathrm{V}_{2}=\mathrm{NM}-92$

LSD

\section{Interaction}

$\mathrm{D}_{1} \times \mathrm{V}_{1}$

$\mathrm{D}_{1} \times \mathrm{V}_{2}$

$\mathrm{D}_{2} \times \mathrm{V}_{1}$

$\mathrm{D}_{2} \times \mathrm{V}_{2}$

$\mathrm{D}_{3} \times \mathrm{V}_{1}$

$\mathrm{D}_{3} \times \mathrm{V}_{2}$

$\mathrm{D}_{4} \times \mathrm{V}_{1}$

$\mathrm{D}_{4} \times \mathrm{V}_{2}$

LSD

\section{Number of grains 1000 grain weight (g) Grain yield (kg per pod \\ $\mathbf{h a}^{-1}$ )}

$53.66 \mathrm{~b}$
$50.00 \mathrm{bc}$
$45.00 \mathrm{c}$
$61.66 \mathrm{a}$
6.77

$58.33 \mathrm{a}$

$46.83 \mathrm{~b}$

4.85

0.22

$11.30 \mathrm{a}$

56.667

$10.80 \mathrm{~b}$

$9.50 \mathrm{c}$

$9.40 \mathrm{c}$

$8.53 \mathrm{~d}$

$9.53 \mathrm{c}$

$9.36 \mathrm{c}$

$8.46 \mathrm{~d}$
$653.90 \mathrm{a}$

$568.79 \mathrm{ab}$

396.92 b

209.21 c

182.54

$502.60 \mathrm{a}$

$411.80 \mathrm{~b}$

72.86

751.11

556.69

618.73

518.85

411.40

382.43

229.17

189.24
66.67

56.66

\section{Biological yield Harvest index $\left(\mathrm{kg} \mathrm{ha}^{-1}\right)$ \\ (\%)}

$\begin{array}{ll}7665.2 \mathrm{a} & 8.4867 \mathrm{a} \\ 7406.5 \mathrm{~b} & 7.6617 \mathrm{ab} \\ 7247.0 \mathrm{c} & 5.4283 \mathrm{~b} \\ 7075.7 \mathrm{~d} & 2.9517 \mathrm{c} \\ 78.32 & 2.42\end{array}$

7400.9 a

$6.6833 \mathrm{a}$

7296.3 b

$5.5808 \mathrm{~b}$

34.18

0.91

7773.3

9.6167

7557

7.3567

7431.7

8.3133

7381.3

7.0100

7272

5.5933

7222

5.2633

7126.7

3.2100

7024.7

2.6933 
Minimum plant height in late planted crop was due to competition competition of developmental stages which results in plant height reduction. On the other hand, rainfall may also be the reason in attaining maximum plant height. Early sown variety enjoyed more period of rainfall during the month of March which effects crop to attain more plant height and late planted crop in month of $12^{\text {th }}$ April provide minimum plant height because during this month distribution of rainfall was not good which effect the plant height.

The data obtained from results are contrary to the results of Aslam et al. (2004) who observed nonsignificant results in case of sowing dates and varieties of mungbean. It was concluded from results that maximum number of pods bearing branches that was produced by AZRI-2006 in $\mathrm{D}_{1}$ ( $1^{\text {st }}$ March) sowing may be due to the genetic ability of variety and the reduction in pod bearing branches may be due to delay in sowing date.

Ananalogous outcome was stated by Uddin et al. (2013) who described that sowing dates considerably have an impact on the grains counts per pod. In his studies higher grains count per pod (14.70) was obtained from crop planted on $15^{\text {th }}$ September and minimum number of grains per pod (9.26) was obtained from $15^{\text {th }}$ October sowing date.

Outcomes of current research experiment are parallel to the outcomes of Rehman et al. (2009) who conveyed that sowing dates and cultivars considerably affected the 1000-grain weight of mungbean. It is evaluated from results those variations in the 1000-grain weight of mungbean is because of the variability among genes in all varieties under different sowing dates. Other factor which may also affect the yield of crop is environmental variations. Late planted crop on $15^{\text {th }}$ April produced more 1000 -grian weight than early planted, may be due to temperature fluctuations because more feasible temperature will be available to crop during the month of April so crop respond well and gave better yield.

Alike outcomes were pragmatic by Singh et al. (2013) who reported that with delay in planting the grain yield of mungbean was decreased. Similar findings were observed by Rehman et al. (2009). So, it is confirmed that sowing dates had great impact on grain yield of mungbean and variation in grain yield is also due to genetic capabilities of mungbean cultivars.
Present outcomes were supported by Ali et al. (2014) findings who observed that in mungbean higher biological yield (8066 $\mathrm{kg} \mathrm{ha}^{-1}$ ) was produced by $15^{\text {th }}$ June sowing and lower biological yield $\left(7270 \mathrm{~kg} \mathrm{ha}^{-1}\right)$ was produced by $15^{\text {th }}$ July sowing. These results are contrary to the finding of Algan (2011) who observed increase in biological yield by delay in sowing dates.

Analogous results were found by Singh et al. (2013) who told that cultivars and sowing dates had substantial effect on harvest index. They stated that the higher grain yield therefore higher the harvest index of crop. While sowing dates and cultivars interaction showed non-significant results.

\section{Conclusions and Recommendations}

From the above results of growth and yield parameters of mungbean cultivars it is concluded that different sowing dates have a substantial effect on above parameters. The results from current research experiment proposed that there is significant chance to get the maximum yield of mungbean if it is cultivated on appropriate time. So, it is endorsed from the above findings that cultivation of mungbean at $1^{\text {st }}$ March is optimized time for attaining supreme yield potential under the agro-ecological environments of Sargodha.

\section{Novelty Statement}

Appropriate sowing time is an important aspect that can affect the growth and yield of any crop. Therefore, in this study sowing time of Mungbam was optimized that will help in timely planting of Mungbean for better yield by using maximum resources.

\section{Author's Contribution}

All authors mentioned in the manuscript have contributed for study, statistical analysis and write-up of manuscript.

Conflict of interest

The authors have declared no conflict of interest.

\section{References}

Abbas, G., M.J. Asghar, M. Rizwan, M. Akram, J. Hussain and F. Ahmad. 2018. Genetic analysis of yield and yield components for the improvement of mungbean germplasm. Pak. 
J. Agric. Res., 31(2): 158-165. https://doi. org/10.17582/journal.pjar/2018/31.2.158.165

Algan, N., 2011. Evaluation of mungbean (Vigna radiata $\mathrm{L}$.) as green manure in Aegean conditions in term of soil nutrition under different sowing dates. Afr. J. Agric. Res., 6(7): 1744-1749.

Ali, M. and S. Gupta. 2012. Carrying Capacity of Indian Agriculture. Pulse crops. Curr. Sci., 102: 874-881.

Ali, S., Khaliq, T., Ahmad, A., Rehman, M., Hussain, S., Rehman, K. and Wajid, M. 2014. Genotypic variations in mungbean yield and its attributes in response to different sowing times. Res. J. Agric. Environ. Manage. 3(5): 255-258.

Amin, M., W. Xiaoguang, L., Song, L. Song, H. Ullah and M.Y. Ashraf. 2014. Penalized selection of variable contribution to enhanced seed yield in mungbean (Vigna radiata L.). Pak. J. Agric. Sci., 51(2): 373-381.

Amin, R., Laskar, R.A., Khan, S., Deb, C.R., Tomlekova, N., Wani, M.R., and Raina, A., 2019. Lentil (Lens culinaris Medik.) diversity, cytogenetics and breeding. In Adv. plant breed. strategies: legumes (pp. 319-369). Springer, Cham.

Aslam, M., M. Hussain, M.A. Nadeem and A.M. Haqqani. 2004. Comparative efficiency of different mungbean genotypes under Agroclimatic conditions of Bhakkar. Pak. J. Life Soc. Sci., 2(1): 51-53.

Awaad, H., and N. El-Naggar. 2018. Role of intercropping in increasing sustainable crop production and reducing the food gap in Egypt. Sustain. Agric. Environ. Egypt. Springer, Cham., Part I pp. 101-118. https://doi. org/10.1007/698_2017_164

Aziz-ur-Rehman, M., S. Kaukab, S. Saeed, M. Aqeel, G. Riasat and C.M. Rafiq. 2019. Prospects of Mungbean as an Additional Crop in Rice Wheat System of Punjab Pakistan. Univ. J. Agric. Res., 7: 136-141. https://doi.org/10.13189/ujar.2019.070303

Chauhan, Y.S. and R.C. Rachaputi. 2014. Defining agro-ecological regions for field crops in variable target production environments: A case study on mungbean in the northern grains region of Australia. Agric. For. Meteorol., 194: 207-217. agrformet.2014.04.007

Garnett, T., 2013. Food sustainability: Problems, perspectives and solutions. Proc. Nutr.
Soc., 72(1): 29-39. https://doi.org/10.1017/ S0029665112002947

Govt. of Pakistan. 2018. Pakistan Economic Survey 2017-2018. Ministry of Finance, Islamabad. 2: 18-19. https://doi.org/10.26652/cjif.2201712

Govt. of Pakistan. 2019. Pakistan Economic Survey 2018-2019. Ministry of Finance, Islamabad. 2: 24-25.

Hozayn, M., M. Zeidan, E.A. El-Lateef and M.A. El-Salam. 2007. Performance of some mungbean (Vigna radiata L.Wilczek) genotypes under late sowing conditions in Egypt. Res. J. Agric. Biol. Sci., 3(6): 972-978.

Hunt, R., 1978. Plant growth analysis. Edward Arnold, U.K., pp. 26-38.

Hussain, A. and S.K. Khalil. 2004. Effect of sowing time and variety on grain yield of mungbean. Sarhad J. Agric., 20: 481-484.

Islam, Q.S., M. Rahman, M. Hossain and M. Hossain. 2011. Economic analysis of mungbean (Vigna radiata L.) cultivation in some coastal areas of Bangladesh. Bangladesh J. Agric. Res., 36(1): 29-40. https://doi.org/10.3329/bjar. v36i1.9227

Khan, B.A., A. Hussain, A. Elahi, M. Adnan, M.M. Amin, M.D. Toor, A. Aziz, M.K. Sohail, A. Wahab and R. Ahmad. 2020. Effect of phosphorus on growth, yield and quality of soybean (Glycine max L.); A review. Int. J. Appl. Res., 6(7): 540-545

Kumar, R. and N. Kumawat. 2014. Effect of sowing dates, seed rates and integrated nutrition on productivity, profitability and nutrient uptake of summer mungbean in Eastern Himalay. Arch. Agron. Soil Sci., 60(9): 1207-1227. https://doi. org/10.1080/03650340.2013.874559

Mondal, M.M.A., A.B. Puteh, M.A. Malek, M.R. Ismail, M.Y. Rafii and M.A. Latif. 2012. Seed yield of mungbean (Vigna radiata (L.) Wilczek) in relation to growth and developmental aspects. Sci. World J., 2012. https://doi. org/10.1100/2012/425168

Monem, R., S.M. Mirtaheri and A. Ahmadi. 2012. Investigation of row orientation and planting date on yield and yield components of mung bean. Ann. Biol. Res., 3(4): 1764-1767.

Moomow, J.C., 1978. International proceedings of the $1^{\text {st }}$ international mungbean symposium, 16-19 August, Univ. of Philippines, Los Banos, AVRDC, Taiwan, pp. 4-5.

Patel, S.R., K.K. Patel and H.K. Parmar. 
2014. Genetic variability, correlation and path analysis for seed yield and its components in green gram [Vigna radiata L. Wilczek]. (Doctoral dissertation, Anand Agricultural University, Anand).

Raina, S.K., Govindasamy, V., Kumar, M., Singh, A.K., Rane, J. and Minhas, P.S. 2016. Genetic variation in physiological responses of mungbeans (Vigna radiata (L.) Wilczek) to drought. Acta Physiol. Plant. 38(11): 1-12.

Raza,M.H., G.U.Sadozai, M.S.Baloch, E.A. Khan, I. Din and K. Wasim. 2012. Effect of irrigation levels on growth and yield of mungbean. Pak. J. Nutr., 11(10): 876. https://doi.org/10.3923/ pjn.2012.974.977

Rehman, A., S. Khalil, S. Nigar, S. Haq, S. Akhtar, A. Khan and S. Shah. 2009. Phenology, plant height and yield of mungbean varieties in response to planting dates. Sarhad J. Agric., 25(2): 147-151.

Sadeghipour, O., 2008. Response of mungbean varieties to different sowing dates. Pak. J. Biol. Sci., 11(16): 2048-2050. https://doi. org/10.3923/pjbs.2008.2048.2050

Shah, F. and W. Wu. 2019. Soil and crop management strategies to ensure higher crop productivity within sustainable environments. Sustainability, 11(5): 1485. https://doi.org/10.3390/su11051485

Sharma, O.P., O.M. Bambawale, J.B. Gopali, S. Bhagat, S. Yelshetty, S.K. Singh and O.P. Singh. 2011. Field guide: Mungbean and urdbean (No. BOOK). National Centre for Integrated Pest Management.

Singh, A.K., P. Kumar and N. Chandra. 2013. Studies on seed production of mungbean (Vigna radiata L.) sown at different sowing dates. J. Environ. Biol., 34(6): 1007-1011.

Singh, A.K., S.S. Singh, V.E.D. Prakash, S. Kumar and S.K. Dwivedi. 2015. Pulses production in india: Present status, sent status, bottleneck and way forward. J. Agric. Search, 2(2): 75-83.

Singh, D. and B. Singh. 2011. Breeding for tolerance to abiotic stresses in mungbean. J. Food Legumes, 24(2): 83-90.

Singh, G., H. Sekhon, H. Ram, K. Gill and P. Sharma. 2010. Effect of date of sowing on nodulation, growth, thermal requirement and grain yield of kharif mungbean genotypes. J. Food Legumes, 23(2): 132-134.

Soomro, N.A. and H.R. Khan. 2003. Response of mungbean genotypes to different dates of sowing in kharif season under rainfed conditions. Asian J. Plant Sci., 2: 377-379. https://doi.org/10.3923/ajps.2003.377.379

Steel, R.G.D., J.H. Torrie and D.A. Dicky. 1997. Principles and procedures of statistics. A biochemical approach, $3^{\text {rd }}$ edition. McGraw Hill Book Int. Co., New York, pp. 172-177.

Torabian, S., S. Farhangi-Abriz and M.D. Denton. 2019. Do tillage systems influence nitrogen fixation in legumes? A review. Soil Tillage Res., 185: 113-121. https://doi.org/10.1016/j. still.2018.09.006

Uddin, F., M. Sarkar and M.H. Rashid. 2013. Level of phosphorus and varietal effect with planting time on see yield and yield contributing characters of mungbean. Bangladesh Res. Publ. J., 9(2): 141-146.

Ullah, A., A. Ali, M. Waseem, M.A. Nadeem, M. Tahir, A. Iqbal and R. Haseeb. 2010. Response of two mungbean cultivars with different phosphorus levels under Faisalabad Condition. Int. J. Appl., 5(5): 621-628.

Watson, D.J., 1947. Comparative physiological studies on the growth of field crops: I. Variation in net assimilation rate and leaf area between species and varieties, and within and between years. Ann. Bot., 11(41): 41-76. https://doi. org/10.1093/oxfordjournals.aob.a083148 